\title{
АНАЛІЗ РЕЗИСТЕНТНОСТІ ДО АНТИМІКОТИЧНИХ ПРЕПАРАТІВ ШТАМІВ ДРІЖДЖОПОДІБНИХ ГРИБІВ РОДУ САNDIDA, ІЗОЛЬОВАНИХ У ХВОРИХ НА ГОСТРИЙ ЛЕЙКОЗ
}

\author{
Скачкова Н. К. \\ ДУ «Інститут гематології та трансфузіологї НАМН України», \\ Київ, Україна

\section{Резюме}

Bступ. За останні десятиріччя спостерігається неухильне зростання кандидозів, y тому числі і у хворих на гострий лейкоз (ГЛ). Необтрунтоване та тривале використання антимікотичних препаратів у схемах лікування пацієнтів призвело до селекиії резистентних итамів Candida spp. Кандидози, обумовлені стійкими до антимікотиків штамами, відрізняються тривалим $i$ тяжким перебігом 3 хронізацією інфекиійного процесу та рецидивами. Тому проблема резистентності збудників кандидозів до антимікотичних препаратів стає актуальною.

Мета. Провести аналіз результатів тестування до антимікотиків дріжджоподібних грибів роду Candida, ізольованих з різних біотопів хворих на ГЛ у 2002 2020 рр., для визначення формування стійкості кандид до антимікотичних препаратів.

Матеріали і методи. Протягом 2002-2020 рр. обстежено 93 хворих на гострий лімфобластний лейкоз (ГЛЛ) та гострий мієлоїдний лейкоз (ГМЛ). 3 різних біотопів пацієнтів на ГЛ було ізольовано та ідентифіковано 93 штами Сапdida spp., щзо були вірогідними $і$ потенційними збудниками інфекційно-запальних ускладнень (ІЗУ). Визначена їхня чутливість до ністатину, амфотерацину В, клотрімазолу, ітраконазолу, флуконазолу, кетоконазолу. У досліджені використані клінічні та мікробіологічні методи.

Результати. За весь період досліджень штами Сandida spp., щуо були ізольовані у хворих на ГЛЛ, виявились найбільи стійкими до ітраконазолу, флуконазолу та кетоконазолу (46,2\%-71,4\%), у хворих на ГМЛ - до ітраконазолу, кетоконазолу, амфотерицину В та флуконазолу (57,8\%-66,7\%). 3 роками спостерігалось збільшення кількості итамів, резистентних до антимікотиків, окрім ністатину, особливо до азолів: у хворих на ГЛЛ - від 0\%-42,9\% у 2002-2005 рр. до $100 \%$ у 2010-2012 рр., у хворих на ГМЛ - від 25,0\%-72,7\% у 2002-2007pр. до 50,0\%$80,0 \%$ y 2011-2020 pp.

Висновки. 3а 2002-2020 рр. рівень резистентності итамів Candida spp., ізольованих у хворих на ГЛ, знаходився у межах від 46,2\% до 71,4\%. Встановлено зростання з роками кількості стійких ізолятів кандид до досліджених 
антимікотичних препаратів (окрім ністатину), особливо до азолів (окрім клотримазолу у хворих на ГМЛ) від 0\%-50,0\% до 80,0\%-100\%. 3 а результатами досліджень іп vitro рекомендовано антимікотичні препарати для профілактики та лікування хворих на ГЛ.

Ключові слова: гострий лейкоз, антимікотики, кандиди, резистентність, чутливість.

Конфлікт інтересів: автори заявляють про відсутність конфлікту інтересів.

Фінансування: дослідження не мало спонсорської підтримки.

\title{
ANALYSIS OF RESISTANCE TO ANTIFUNGAL DRUGS OF STRAINS OF YEAST FUNGI OF THE GENUS CANDIDA ISOLATED IN PATIENTS WITH ACUTE LEUKEMIA
}

\author{
Skachkova N. K. \\ SI «Institute of Hematology and Transfusiology of NAMS of Ukraine», \\ Kyiv, Ukraine
}

\begin{abstract}
Introduction. In recent decades, there has been a steady increase of candidiasis, including in patients with acute leukemia $(A L)$. Unreasonable and prolonged use of antifungal drugs (AFD) in treatment regimens has been leaded to the selection of Candida spp. resistant strains Candidosis caused by antifungal-resistant strains are long and severe with chronic infection and recurrence. Therefore, the problem of candidosis pathogens' resistance to AFD is becoming increasingly important.

Aim. To analyze the formation of resistance to AFD the Candida yeast-like fungi, isolated from different habitats of patients with AL in 2002-2020 yy.

Materials and methods. In the research period 93 patients with acute lymphoblastic leukemia (ALL) and acute myeloid leukemia (AML) have been inspected. From different biotopes of patients with AL 93 Candida spp. strains have been isolated and identified as probable and potential pathogens of infectious and inflammatory complications (IIC). Their sensitivity to nystatin, amphotericin B, clotrimazole, itraconazole, fluconazole, ketoconazole was determined. Clinical and microbiological research methods have been used.
\end{abstract}

Results. It has been established, that Candida spp. strains isolated from patients with ALL were the most resistant to itraconazole, fluconazole and ketoconazole $(46.2 \%$ $71.4 \%)$; in patients with AML - to itraconazole, ketoconazole, amphotericin $B$ and fluconazole (57.8\% - 66.7\%). Over the years, there has been an increase in the number of resistant strains to antifungals: in patients with ALL - from 0\%-42.9\% in 20022005 yy. to $100 \%$ in 2010-2012 yy.; in patients with AML - from $25.0 \%-72.7 \%$ in 2002-2007 yy. up to $50.0 \%-80.0 \%$ in 2011-2020 yy. 
Conclusions. During 2002-2020 yy., the level of Candida spp. strains resistance isolated from patients with AL ranged from $46.2 \%$ to $71.4 \%$. The number of resistant candida isolates to the studied AFD (except nystatin), especially to azoles (except clotrimazole in patients with AML) from 0\%-50.0\% to $80.0 \%-100 \%$ has been established over the years. According to the results of in vitro studies, AFD are recommended for the prevention and treatment of patients with AL.

Keywords: acute leukemia, antifungals, candida, resistance, sensitivity.

\section{Вступ}

В Україні, як і в інших країнах світу, спостерігається неухильне зростання мікозів. Це пов'язано 3 негативною дією різних факторів сучасної цивілізації на організм людини i, особливо, на систему імунітету: використання антимікробних препаратів широкого спектру дії, супутні захворювання, інфекції, онкопатологія та інше. За даними епідеміологічних досліджень частота виявлення мікозів серед дорослих становить від $7 \%$ до $20 \%$. Грибкові інфекцій спричиняють тяжкі ускладнення і збільшують летальність пацієнтів 3 імунодефіцитним станом. Групою ризику залишаються хворі з фебрильною нейтропенією після проведення цитостатичної терапії, особливо хворі на гострий лейкоз (ГЛ) [1]. Відомо, що розвиток захворювань слизової оболонки ротової порожнини залежить від стану імунітету пацієнта, і часто перші ознаки мікозу проявляються у ротовій порожнині, а саме у 72,0 \%-91,9 \% хворих на ГЛ [2].

Серед найпоширеніших збудників мікозів провідне місце займають умовно-патогенні дріжджоподібні гриби роду Candida. Вони обумовлюють широкий діапазон інфекцій - від захворювань шкіри та слизових оболонок, що не загрожують життю, до інвазивних процесів, з ушкодженням внутрішніх органів. Відомо, що найбільш частим збудником, як системних, так і поверхневих кандидозів, $\epsilon$ Candida albicans, aле не виключена етіологічна роль інших видів із групи non-albicans, a caме: C. krusei, C. glabrata, C. tropicalis, C. parapsilosis та ін., які стають все частішою причиною інвазивного кандидозу [3].

Лікування інфекції, збудником якої $\epsilon$ дріжджоподібні гриби роду Candida. може суттєво змінюватися залежно від анатомічної локалізації інфекції, основного захворювання, імунного статусу пацієнта, факторів ризику, видів кандид, їхньої чутливості до протигрибкових препаратів. Активне застосування інвазивних медичних засобів: катетери, стенти, шунти, протези, ендотрахеальні трубки та ін., призвело до збільшення ізолятів гемокультури Candida spp., таких, що створюють біоплівки. Летальність при кандидемії зі збудником Candida spp. у складі біоплівок, достовірно вище порівняно зі збудниками, які не формують біоплівку 
(51,2\% проти $31,7 \%, p=0,004)$ [4]. Подібна ситуація спостерігається серед пацієнтів відділень реанімації, інтенсивної терапії, де домінуючим видом серед виділених культур $є$ Candida albicans [5]. Кандидомікоз залишається одним з тяжких інфекційних ускладнень і у хворих, які перебувають у відділеннях гематології.

Вибір антимікотичних препаратів при кандидозах для системного застосування вкрай обмежений. Доступні класи включають полієни, азоли і ехінокандини [6].

Необгрунтоване використання антимікотиків, тривале їх використання у схемах лікування хворих безперечно супроводжується формуванням резистентності грибів до цих препаратів. Інфекції, збудниками яких $\epsilon$ резистентні штами, відзначаються тривалим і тяжким перебігом 3 хронізацією інфекційного процесу та рецидивами, подовжують термін перебування у стаціонарі, мають негативний прогноз для пацієнтів. Резистентність мікроорганізмів до антимікробніх препаратів набуває глобального характеру, що безперечно, стосується і дріжджоподібних грибів роду Candida. Тому проблема резистентності кандид до антимікотиків стає все більш актуальною.

Мета. Провести аналіз результатів тестування до антимікотиків дріжджоподібних грибів роду Candida, ізольованих з різних біотопів хворих на ГЛ за 2002-2020 рр., для визначення формування стійкості кандид до антимікотичних препаратів.

\section{Матеріали і методи}

За період 2002-2020 pр. у 93 хворих на гострий лімфобластний лейкоз (ГЛЛ) та гострий мієлоїдний лейкоз (ГМЛ) зі слизових оболонок носової порожнини, зіву та вмісту кишечника було ізольовано й ідентифіковано 93 штами Candida spp., що були визначені як вірогідні, так і потенційні збудники інфекційно-запальних ускладнень (ІЗУ).

Ідентифікацію ізолятів проводили за системою Kurtzman et Fell на основі отриманих даних про морфолого-культуральні, фізіолого-біохімічні характеристики культур [7]. Чутливість in vitro штамів Candida spp. до 6 антимікотиків (ністатин, клотримазол, амфотерицин В, ітраконазол, флуконазол і кетоконазол) визначали диско-дифузійним методом на поживному середовищі агар Сабуро (хлорамфеніколовий агар Сабуро, Франція) [8]. 


\section{Результати та їх обговорення}

Загальна характеристика результатів тестування до антимікотиків штамів Candida spp., ізольованих із біотопів хворих на ГЛ у 20022020 pр., представлено у таблиці 1 (у табл. 1, 2, 3 відсоток проміжних штамів не представлено). За даними таблиці штами Candida spp., що були виділені у хворих на ГЛЛ за весь період досліджень, виявились найбільш стійкими до ітраконазолу, флуконазолу та кетоконазолу (від 46,3 \% до 71,4 \%), у хворих на ГМЛ - до ітраконазолу, кетоконазолу, амфотерицину В та флуконазолу (від 57,8 \% до 66,7 \%). Штами Candida spp., які були ізольовані у пацієнтів на ГМЛ, були більш стійкими до ністатину $(22,0 \%)$, ітраконазолу $(57,9 \%)$ та амфотерицину В $(60,0 \%)$, ніж у хворих на ГЛЛ (13,0 \%; 46,2 \% та 39,1\%, відповідно).

Таким чином, протягом 2002-2020 p.p. у пацієнтів на ГМЛ ізолювалися штами Candida spp. більш резистентні до більшості використаних нами антимікотиків, ніж у хворих на ГЛЛ. Але для пояснення цього факту необхідно провести додаткові дослідження.

Таблиця 1. Загальна характеристика тестування до антимікотиків штамів Candida spp., ізольованих з біотопів хворих на ГЛ $(\mathrm{n}=93)$ y 2002-2020 pp.

\begin{tabular}{|l|c|c|c|c|}
\hline \multirow{2}{*}{\multicolumn{1}{|c|}{ Антимікотики }} & \multicolumn{3}{|c|}{ Кількість штамів, (\%) } \\
\cline { 2 - 5 } & \multicolumn{2}{|c|}{ стійкі } & \multicolumn{2}{c|}{ чутливі } \\
\cline { 2 - 5 } & ГЛЛ & ГМЛ & ГЛЛ & ГМЛ \\
\hline Ністатин & 13,0 & 22,9 & 87,0 & 74,3 \\
\hline Амфотерицин В & 39,1 & 60,0 & 60,9 & 35,7 \\
\hline Клотримазол & 34,8 & 34,3 & 65,2 & 64,3 \\
\hline Ітраконазол & 46,2 & 57,8 & 15.4 & 8,9 \\
\hline Флуконазол & 60,0 & 66,7 & 10,0 & 9,2 \\
\hline Кетоконазол & 71,4 & 58,9 & 28,6 & 33,3 \\
\hline
\end{tabular}

Результати тестування до антимікотиків штамів Candida spp., ізольованих із біотопів хворих на ГЛЛ у 2002-2005 pp. та 2010-2012 pp., представлено у таблиці 2.

За даними таблиці 2 з роками спостерігалось збільшення кількості штамів резистентних до клотримазолу, ітраконазолу, флуконазолу і кетоконазолу, відсоток яких сягав $100 \%$ у 2010-2012 рр., тоді як у 20022005 рр. стійкими було від $0 \%$ до 42,9\% ізолятів. Водночас зростала чутливість до ністатину від 76,9\% у 2002-2003 рр. до $100 \%$ у 2004 2005 pp. і залишалася на цьому ж рівні у 2010-2012 pр.; амфотераціну В 53,8 \% у 2002-2003 pp., 66,7 \%-71,4 \% у 2004-2005pp. та 2010-2012 pp. 
Таблиця 2. Характеристика тестування до антимікотиків штамів

Candida spp., ізольованих з біотопів хворих на ГЛЛ $(\mathbf{n}=\mathbf{2 3})$ y 2002-2005 pp. та 2010-2012 pp.

\begin{tabular}{|l|c|c|c|c|c|c|}
\hline \multirow{3}{*}{ Антимікотики } & \multicolumn{6}{|c|}{ Кількість штамів, (\%) } \\
\cline { 2 - 7 } & \multicolumn{3}{|c|}{ стійкі } & \multicolumn{3}{c|}{ чулливі } \\
\cline { 2 - 7 } & $\begin{array}{c}\mathbf{2 0 0 2 -} \\
\mathbf{2 0 0 3}\end{array}$ & $\begin{array}{c}\mathbf{2 0 0 4}- \\
\mathbf{2 0 0 5}\end{array}$ & $\begin{array}{c}\mathbf{2 0 1 0}- \\
\mathbf{2 0 1 2}\end{array}$ & $\begin{array}{c}\mathbf{2 0 0 2}- \\
\mathbf{2 0 0 3}\end{array}$ & $\begin{array}{c}\mathbf{2 0 0 4}- \\
\mathbf{2 0 0 5}\end{array}$ & $\begin{array}{c}\mathbf{2 0 1 0}- \\
\mathbf{2 0 1 2}\end{array}$ \\
\hline Ністатин & 23,1 & 0 & 0 & 76,9 & 100 & 100 \\
\hline Амфотерицин В & 46,2 & 28,6 & 33,3 & 53,8 & 71,4 & 66,7 \\
\hline Клотримазол & 23,1 & 28,6 & 100 & 76,9 & 71,4 & 0 \\
\hline Ітраконазол & 0 & 42,9 & 100 & 33,3 & 14,3 & 0 \\
\hline Флуконазол & - & 42,9 & 100 & - & 14,3 & 0 \\
\hline Кетоконазол & - & 33,3 & 100 & - & 50,0 & 0 \\
\hline
\end{tabular}

Результати тестування до антимікотиків штамів Candida spp., ізольованих із біотопів хворих на ГМЛ за 2002-2020 pp., представлено у таблиці 3. Як видно із наведених даних, кількість стійких до антимікотиків штамів дріжджоподібних грибів роду Candida у цієї категорії хворих з роками теж збільшувалась (окрім ністатину). Так, резистентність штамів Candida spp. до антимікотичних препаратів у 2002-2007 pp. знаходилась у межах 25,0\%-72,7\%, а у 2011-2020 pр. найчастіше в межах 50,0 \%-90,0\%.

Таблиця 3. Характеристика тестування до антимікотиків штамів

Candida spp., ізольованих з біотопів хворих на ГМЛ $(\mathbf{n}=\mathbf{7 0})$ у 2002-2020 pp.

\begin{tabular}{|c|c|c|c|c|c|c|c|c|c|c|}
\hline \multirow{3}{*}{$\begin{array}{c}\text { Анти- } \\
\text { мікотики }\end{array}$} & \multicolumn{10}{|c|}{ Кількість штамів, (\%) } \\
\hline & \multicolumn{5}{|c|}{ стійкі } & \multicolumn{5}{|c|}{ чутливі } \\
\hline & $\begin{array}{c}2002- \\
2003\end{array}$ & $\begin{array}{c}2004- \\
2005\end{array}$ & $\begin{array}{c}2006- \\
2007\end{array}$ & $\begin{array}{c}2011- \\
2014\end{array}$ & $\begin{array}{c}2015- \\
2020\end{array}$ & $\begin{array}{c}2002- \\
2003\end{array}$ & $\begin{array}{c}2004- \\
2005\end{array}$ & $\begin{array}{c}2006- \\
2007\end{array}$ & $\begin{array}{c}2011- \\
2014\end{array}$ & $\begin{array}{c}2015- \\
2020\end{array}$ \\
\hline Ністатин & 37,5 & 31,8 & 0 & 20,0 & 10,0 & 62,5 & 59,1 & 100 & 80,0 & 90,0 \\
\hline $\begin{array}{l}\text { Амфотери- } \\
\text { цин В }\end{array}$ & 68,8 & 40,9 & 41,7 & 80,0 & 90,0 & 31,3 & 54,5 & 41,7 & 20,0 & 10,0 \\
\hline Клотримазол & 43,8 & 36,4 & 25,0 & 10,0 & 50,0 & 56,3 & 59,1 & 75,0 & 90,0 & 50,0 \\
\hline Ітраконазол & 50,0 & 68,2 & 41,7 & 60,0 & - & 16,7 & 4,5 & 16,7 & 0 & - \\
\hline Флуконазол & - & 72,7 & 50,0 & 60,0 & 80,0 & - & 13,6 & 0 & 10,0 & 10,0 \\
\hline Кетоконазол & - & 47,4 & 50,0 & 70,0 & 80,0 & - & 42,1 & 33,3 & 30,0 & 20,0 \\
\hline
\end{tabular}


Однак, протягом 2002-2007 pp. у хворих на ГМЛ спостерігалося зниження стійкості штамів дріжджоподібних грибів роду Candida до всіх досліджених антимікотиків. Так, кількість резистентних ізолятів у 2002 2005 рр. коливалася від 31,8 \% до 72,7\%, а у 2006-2007 рр. від $0 \%$ до 50,0 \%. 32011 р. до 2020 р. було встановлено різке підвищення кількості стійких до антимікотиків штамів Candida spp., а саме, у більшості випадків від 50,0\% до 90,0\%.

Слід зазначити, що протягом усього періоду досліджень найвищий рівень чутливості кандид, ізольованих у хворих на ГЛ, спостерігався до ністатину - 59,1 \%-100\%, та клотримазолу - 50,0\%-90,0\%. До амфотерацину В чутливими були $31,3 \%-71,4 \%$ штамів Candida spp. у 2002 2007 pр., але вже у 2011-2020 pр. кількість чутливих ізолятів знизилась до $10,0 \%-20,0 \%$ у пацієнтів з ГМЛ.

Таким чином, у хворих на ГЛ у період з 2002 р. по 2020 р. спостерігалося зростання рівня резистентності штамів Candida spp. до антимікотичних препаратів (окрім ністатину), поступово або з коливаннями у бік зниження і подальшого підвищення кількості стійких ізолятів.

За результатами тестування до антимікотичних препаратів штамів дріжджоподібних грибів роду Candida, ізольованих у хворих на ГЛ з різних біотопів протягом 2002-2020 рр., важливим $\epsilon$ встановлення зростання рівня резистентності кандид до антимікотиків азолового ряду (похідні тріазолу - ітраконазол, флуконазол; імідазолу - кетоконазол і клотримазол): до 50,0 \% - 80,0 \% у хворих на ГМЛ у 2015-2020 pp. і до $100 \%$ у хворих на ГЛЛ у 2010-2012 рр. Не менш важливим є встановлення факту високої чутливості (від 59,1\% до 100 \%) штамів Candida spp. протягом усього періоду досліджень до полієнів ністатину та амфотерицину В, до останнього високий рівень чутливості спостерігався у хворих на ГЛЛ і становив від $53,8 \%$ до $71,4 \%$, а у пацієнтів з ГМЛ знаходився у межах 31,3\%-54,5\% у 2002-2007 pp., але у 2011-2020 pp. знизився до 10,0 \%-20,0 \%. Протягом 2002-2020 pр., незважаючи на зростання резистентності кандид до азолів, високо чутливими штами Candida spp. були і до клотримазолу (56,3\%-90,0\%), окрім 2010-2012 pp. у хворих на ГЛЛ (чутливість кандид знизилась до 0 \%).

Високі рівні резистентності дріжджоподібних грибів роду Candida до азолів - ітраконазолу та флуконазолу, були виявлені і у дослідженнях in vitro на клінічних ізолятах K. Zomorodian et al. (2016) [9].

Результати наших досліджень корелюють і з даними інших авторів. Так, І. Г. Анохіна і співавт. (2020) встановили, що протягом 2014-2020 pp. чутливість клінічних ізолятів кандид до таких азолів, як флуконазол та 
ітраконазол, знизилась $3 \quad 70,6 \%$ до $17,1 \%$ та $3 \quad 94,1 \%$ до $58,5 \%$, відповідно [10]. Зросла резистентність і до клотримазолу, ністатину та амфотерацину В, але чутливість до цих препаратів залишилась на високому рівні від 73,2 \% до 81,0\%. Дані дослідження F. Choukri et al. (2014) підтверджують чутливість C. albicans до найбільш часто вживаних місцевих антимікотиків, а саме - до полієну ністатину. Автори підкреслюють, що це може служити аргументом на користь лікування поверхневих кандидозів, збудниками яких $є$ і різні види Candida non-albicans, та можуть бути альтернативою до азолів [11].

За даними наукової літератури аналіз чутливості до антимікотиків показав, що $62,7 \%$ штамів C. albicans були чутливими до ністатину, $32,9 \%$ - до клотримазолу, і лише $6,7 \%$ - до кетоконазолу, 6,0 \% - до флуконазолу. Відповідно, решта штамів C. albicans були резистентними до названих антимікотиків. Штами C. krusei були високо резистентними до азолів: клотримазолу $-68,8 \%$, кетоконазолу - 93,8 \% і флуконазолу $100 \%$. Частка резистентних до ністатину штамів склала 43,8 \%. Ізоляти С. glabrata були чутливими до ністатину $-84,6 \%$, клотримазолу $-61,5 \%$, кетоконазолу - 23,1\% і флуконазолу - 23,1\%. Кількість резистентних штамів склала, відповідно: 15,4 \%, 38,5 \%, 76,9\% і 76,9\%. Більшисть ізолятів C. krusei виявили чутливість до ністатину 85,7 \%, у той час, як до інших антимікотиків визначено високу частоту резистентності: до клотримазолу - 71,4 \%, кетоканазолу - $100 \%$ і флуконазолу $-100 \%$, що співпадає і з результатами наших досліджень [12].

Деякі автори констатують, що кандидоз слизової оболонки ротової порожнини є частим ускладненням у хворих на лейкоз і «маркером» порушення імунітету внаслідок неефективності лікування препаратами азолового ряду -флуконазолом або ітраконазолом [2]. Однак, дослідження інших авторів показали, що флуконазол, залишається препаратом вибору для лікування кандидозів, поскільки результати дослідження in vitro не завжди свідчать про клінічну резистентність, і ізоляти, що були стійкими до антимікотиків in vitro, можуть бути чутливими in vivo $[9,13,14]$.

Частота виявлення резистентних штамів різних видів дріжджоподібних грибів роду Candida до антимікотиків може варіювати не тільки по різних країнах, але й у межах однієї країни, може змінюватись по роках, тобто має динамічний i, можливо, зворотній характер [9].

Отже, за результатами моніторингу рівнів резистентності до антимікотичних препаратів in vitro штамів кандид, ізольованих з різних біотопів хворих на ГЛ протягом 2002-2020 рр., встановлено, що частота виявлення стійких ізолятів дріжджоподібних грибів роду Candida до антимікотиків, 
особливо до азолів, з роками зростала. Такі препарати, як полієни ністатин і амфотерацин В та азол клотримазол, до яких встановлено високий рівень чутливості штамів Candida spp. протягом тривалого періоду спостережень, можуть залишатися препаратами вибору для лікування пацієнтів 3 кандидозами, у тому числі і хворих на ГЛ з ІЗУ кандидозної етіології.

Отримані дані обумовлюють необхідність проведення постійніх досліджень чутливості до антимікотичних препаратів в медичних закладах для запобігання розвитку резистентності грибів, у тому числі і кандид, до антимікотиків. Моніторинг локальних рівнів чутливості, як перший крок до подолання антимікотичной резистентності, сприяє розробці рекомендацій щодо профілактики, емпіричної терапії та ведення пацієнтів 3 кандидозом.

\section{Висновки}

1. Встановлено, що за період дослідження 2002-2020 pp. ізольовані $з$ різних біотопів хворих на ГЛ штами Candida spp., були найбільш стійкими до ітраконазолу, флуконазолу та кетоконазолу (від 46,2 \% до 71,4 \%) у пацієнтів з ГЛЛ, а у пацієнтів з ГМЛ - до ітраконазолу, кетоконазолу, амфотерицину В та флуконазолу (від 57,8 \% до 66, 7\%).

2. Встановлено зростання рівня резистентності ізольованих штамів Candida spp. до досліджених антимікотичних препаратів (окрім ністатину) протягом 2002-2020 рр., особливо до азолів, від 0\%-50,0\% до 80,0 \%$100 \%$ (окрім клотримазолу у хворих на ГМЛ).

3. Серед досліджених антимікотиків за результатами тестування in vitro за останні два десятиліття для профілактики і лікування хворих на ГЛ з кандидозом препаратами вибору виявились амфотерицин В, кл отримазол і ністатин

\section{Література}

1. Токмакова СИ, Бондаренко ОВ, Куклина НВ, Прокопьев ВВ, Шестун КБ, Киселева КА. Чувствительность к антимикотическим препаратам у пациентов с кандидозом полости рта. Проблемы стоматологии. 2014;1:27-28.

2. Булиева НБ. Грибковые инфекции как осложнение химиотерапии у больных гемобластозами. Медицинский совет. 2012;1:50-55.

\section{References}

1. Tokmakova SI, Bondarenko OV, Kuklina NV, Prokopiev VV, Shestun KB, Kiseleva KA. Sensitivity to Antibacterial Drugs in Pacients with Oral Candidiasis. Actual problems of stomatology. 2014;1:27-28 (in Russian).

2. Bulieva NV. Fungal Infektions as a Complication of Chemotherapy in patients with Hematological Malignancies. 2012;1:50-55. 
3. Кириллова ВП, Ткач ТМ, Лямин АВ, Трунин ДА, Серазетдинова АР. Микробный пейзаж слизистой оболочки полости рта больных лейкозом на фоне клинической картины кандидоза. Оренбургский медицинский вестник. 2015; 3,3:34-40.

4. Новикова ВВ, Езов СГ, Селиванова АИ. Анализ видового состава и чувствительности клинических изолятов Candida spp. к современным антимикотикам. Медицинский альманах. 2017;29(47):138-141.

5. Спасибова ЕВ, Савичева АM. Оценка чувствительности in vitro дрожжеподобных грибов рода Candida и пробиотического штамма Lactobacillus rhamnosus к антимикотическим препаратам. Журнал акушерства и женских болезней. 2019; 68,5:83-89.

6. Мальчикова АО, Клясова ГА. Формирование биопленок у изолятов Candida spp., выделенных из гемокультуры от больных с опухолями и без опухолей системы крови. Клиническая микробиология и антимикробная химиотерапия. 2018; 20,2:126-130.

7. Kurtzman CP, Fell JW. The yeasts. A taxonomic study. Elsevier Amsterdam et. $1998 ; 1055 \mathrm{p}$.

8. Про затвердження методичних вказівок «Визначення чутливості мікроорганізмів до антибактеріальних препаратів»/ Наказ МО3 України № 167 від 05.04.2007 р. К., 2007. $113 \mathrm{c}$.

9. Zomorodian K, Bandegani A, Mirhendi H. et al. In Vitro Susceptibility and Trailing Growth Effect of Clinical Isolates of Candida Species
3.Kirilova VP, Tcach TM, Lyamin AV, Trunin DA, Serazetdinova AR. Microbal Landscape of Mucous Membrane of Cavity of Mouth of Patients by a Leucosis on a Backoround clinical Presentotion of Candidiasis. Orenburgskiy meditsinskiy vestnik. 2015; 3,3:34-40 (in Russian).

4. Novikova VV, Ezov SG, Selivanova AI. Analiz vidovogo sostava i chuvstvitelnosti klinicheskih izolyatov Candida spp. $\mathrm{k}$ sovremennyim antimikotikam. Meditsinskiy almanah. 2017;29(47):138-141 (in Russian).

5. Spasibova EV, Savicheva AM. In vitro Antimicotic Sensitivity of the Genus Candida yeast and Lactobacillus Rhan nosus Probiotic Strain. Journal of Obstetrics and Women's Diseases. 2019; 68,5:83-89 (in Russian).

6. Malchikova AO, Klyasova GA. Biofilm formetion by Candids spp. Isolated from Blood Culture in Pacients with or without Hamatological Malignancies. Klinicheskaya mikrobiologiya i antimikrobnaya himioterapiya. 2018; 20,2:126-130 (in Russian).

7. Kurtzman CP, Fell JW. The yeasts. A taxonomic study. Elsevier Amsterdam et. 1998; $1055 \mathrm{p}$.

8. Pro zatverdzhennya metodichnih vkazivok «Viznachennya chutlivosti mikroorganizmiv do antibakterialnih preparative». Nakaz MOZ Ukrayini № 167 vId 05.04.2007 r. K., 2007. $113 \mathrm{~s}$ (in Ukrainian).

9. Zomorodian K, Bandegani A, Mirhendi H. et al. In Vitro Susceptibility and Trailing Growth Effect of Clinical Isolates of Candida Species 
to Azole Drugsю. Jundishapur J Microbiol. 2016; 9 (2): e28666.

10. Ахапкина ИГ, Глушакова АМ, Родионова ЕН, Качалкин АВ. Эффективность антифунгальных препаратов в отношении грибов рода Candida, выделенных в Московском регионе. Антибиотики и Химиотерапия. 2020;65(3-4):16-22.

11. Choukri F, Benderdouche M, Sednaouiln $P$. In vitro susceptibility profile of 200 recent clinical isolates of Candida spp. to topical antifungal treatments of vulvovaginal candidiasis, the imidazoles and nystatin agents. Journal de Mycologie Medicale. 2014; 24:303-307.

12. Желтикова ТМ. Мониторинг резистентности клинических штаммов дрожжей род Candida к флаконазолу (Краткий обзор литературы). Медицинский совет. 2017: 2:70-74.

13. Лысенко ОВ. Изучение чувствительности к антигрибковым препаратам микрофлоры больных длительно получающих антибактериальную терапию. Медицинские науки. 2016;2,446,3: 60-64.

14. Скляр ТВ., Лаврентьєва КВ., Курагіна НВ., Мазурова ВА. Особливості чутливості до антимікотичних препаратів грибів роду Candida. Освіта і наука. Міжнародний науковий журнал. 2019; 2(27):4853.

Надійшла: 16.08.2021

Контакти:igtmicrob@ukr.net to Azole Drugsю. Jundishapur J Microbiol. 2016; 9 (2): e28666.

10. Akhapkina IG., Glushakova AM., Rodionova EN., Kachalkin AV. The Effectiveness of Antifungal Agents Against Yeasts of Candida Genus Isolated in Moscow Region. Antibiotics and Chemotherapy. 2020;65(34):16-22 (in Russian).

11.Choukri F, Benderdouche M, SednaouiIn $P$. In vitro susceptibility profile of 200 recent clinical isolates of Candida spp. to topical antifungal treatments of vulvovaginal candidiasis, the imidazoles and nystatin agents. Journal de Mycologie Medicale. 2014;24:303-307.

12.Zhelticova TM. Monitoring the Resistance of Clinical Strains of Candida yeast to Fluconazole (a briff Literature Review). Medical Council / Meditsinskiy Sovet.2017:2:70-74 (in Russian).

13.Lysenko OV. Study of Sensitivity to Antimycotik Drugs Microflora of Pacients Receiving long term Antibacterial Therapy. International Research Journal Madical sciences. 2016;2,446,3: 60-64 (in Russian).

14. Cklyar T, Lavrentyeva C, Kuragina N, Mazurova V. Features of sensitive to Antimicotic Drugs of Mushrooms of the Genus of Candida. Education and Science International Scientific Journal. 2019; 2(27):48-53 (in Ukrainian). 